University of Nebraska - Lincoln

DigitalCommons@University of Nebraska - Lincoln

Faculty Publications from the Harold W. Manter Laboratory of Parasitology

January 2008

\title{
Helminths of Small Mammals (Chiroptera, Insectivora, Lagomorpha) from Mongolia with a Description of a New Species of Schizorchis (Cestoda: Anoplocephalidae)
}

\author{
David S. Tinnin \\ University of Nebraska-Lincoln, hobbit@bigred.unl.edu \\ Scott Lyell Gardner \\ University of Nebraska - Lincoln, slg@unl.edu \\ Sumiya Ganzorig \\ Hokkaido University, sganzorig@yahoo.com
}

Follow this and additional works at: https://digitalcommons.unl.edu/parasitologyfacpubs

Part of the Parasitology Commons

Tinnin, David S.; Gardner, Scott Lyell; and Ganzorig, Sumiya, "Helminths of Small Mammals (Chiroptera, Insectivora, Lagomorpha) from Mongolia with a Description of a New Species of Schizorchis (Cestoda: Anoplocephalidae)" (2008). Faculty Publications from the Harold W. Manter Laboratory of Parasitology. 11.

https://digitalcommons.unl.edu/parasitologyfacpubs/11

This Article is brought to you for free and open access by the Parasitology, Harold W. Manter Laboratory of at DigitalCommons@University of Nebraska - Lincoln. It has been accepted for inclusion in Faculty Publications from the Harold W. Manter Laboratory of Parasitology by an authorized administrator of DigitalCommons@University of Nebraska - Lincoln. 


\title{
Helminths of Small Mammals (Chiroptera, Insectivora, Lagomorpha) from Mongolia with a Description of a New Species of Schizorchis (Cestoda: Anoplocephalidae)
}

\author{
David S. Tinnin, ${ }^{1,4}$ Scott L. Gardner, ${ }^{1}$ And Sumiya Ganzorig ${ }^{2,3}$ \\ ${ }^{1}$ Harold W. Manter Laboratory of Parasitology, Nebraska State Museum, W 529 Nebraska Hall University of \\ Nebraska—Lincoln, Lincoln, Nebraska 68588, U.S.A. (e-mail: hobbit@bigred.unl.edu, slg@unl.edu), \\ ${ }^{2}$ Department of Zoology, Faculty of Biology, National University of Mongolia, and \\ ${ }^{3}$ Laboratory of Parasitology, Graduate School of Veterinary Medicine, Hokkaido University, Sapporo 060, \\ Japan (e-mail: sganzorig@yahoo.com)
}

\begin{abstract}
Fifty-eight individuals belonging to 10 species of bats, insectivores, and pikas were examined for helminths from 4 collection sites in Mongolia in 1999. Two species of bats (Vespertilio murinus and Eptesicus gobiensis) were infected with a single species of trematode (Plagiorchis vespertilionis), which represents a new record for the country. One individual of E. gobiensis also harbored 1 unidentified filaroid nematode. The acanthocephalan Moniliformis moniliformis was found in the hedgehog Hemiechinus auritus. Cestodes in the genus Catenotaenia and the herein described Schizorchis mongoliensis $\mathrm{n}$. sp. were recovered from pikas belonging to the species Ochotona alpina. Schizorchis mongoliensis $\mathrm{n}$. sp. is distinguished from other members of the genus by shorter strobila length accompanied by earlier maturation of proglottids, as well as a distinct vaginal valve and secondary lateral seminal receptacle.

KEY WORDS: Mongolia, helminth, trematode, Plagiorchis, nematode, cestode, Schizorchis, Catenotaenia, bat, Vespertilio, Eptesicus, pika, Ochotona, hedgehog, Hemiechinus
\end{abstract}

In recent years, a concentrated effort has been made to understand the biology, distribution, population density, and behavior of species of mammals comprising the "charismatic megafauna" (particularly ungulates and large carnivores) of Mongolia (Reading, Amgalanbaatar, and Lhagvasuren 1999; Reading, Mix, et al., 1999), but comparative data are sorely lacking for the small mammals of the region (Tinnin et al., 2002). Although some baseline biodiversity survey data are available, little published information exists in the literature on the diminutive mammals of the region (Mallon, 1985; Tinnin et al., 2002). Even fewer published data are available that describe the diversity of parasites of small mammals, although a more extensive literature base, including more than 60 papers, has been generated on the plague bacillus [Yersinia pestis (Lehmann and Neumann, 1896)], the vector fleas, and reservoir rodents in Mongolia (Krasnov, personal communication). Despite this important work, few specimens of parasites or hosts were deposited as vouchers in accessible curated collections or museums. In our literature review, we documented 31 species of helminths, primarily cestodes and nematodes, that were reported from individuals representing 20 species of small mammals (Tenora and Murai, 1975; Danzan, 1978; Ganzorig et al., 1996;

\footnotetext{
${ }^{4}$ Corresponding author.
}

Ganzorig, 1998 unpublished thesis, Graduate School of Veterinary Medicine, Hokkaido University, Japan; Ganzorig et al., 1998; Suhbat and Ganzorig, 1998; Ganzorig, Tenora, et al., 1999; Ganzorig, Batssaikan, et al., 1999; Ganzorig et al., 2003). Fifty-three species of the small mammals that occur in Mongolia or in adjacent countries have never been reported as having been examined for endoparasites. For example, the parasite fauna of bats is unknown. There is only 1 report of a single individual of Plecotus auritus (Linnaeus, 1758) being examined for endoparasites, and this specimen was uninfected (Meszaros, 1974).

Because of this dearth of information on parasites of small mammals of Mongolia, and after we were invited to work with the Mongolians on a U.S. National Science Foundation international long-term ecological research program site visit, we concentrated on collecting mammals and their parasites from 9 July through 2 August 1999. This preliminary work resulted in broad scale baseline biodiversity collecting at 13 different sites and has now expanded into a survey of small mammal and parasite diversity in Mongolia (Tinnin et al., 2002). The results of the examination for helminths of 58 individual bats, shrews, hedgehogs, and pikas are presented in this study.

\section{MATERIALS AND METHODS}

Bats were collected from 2 localities in Mongolia in July 1999. The first site, Ulaan Tsutgaalan $\left(46^{\circ} 47^{\prime} 13^{\prime \prime} \mathrm{N}\right.$, 
$101^{\circ} 57^{\prime} 47^{\prime \prime} \mathrm{E}, 1,850 \mathrm{~m}$ elevation) is located in the Khangai Mountains of Övörkhangay Aimag (province) in west central Mongolia. The surrounding area is mountain steppe habitat cut through by the Orkhon River. The river canyon (ca. $200 \mathrm{~m}$ wide by $50 \mathrm{~m}$ deep) is steep sharply cut rock with a mixed Pinus, Populus, and Larix forest along the riverbank. Bats were captured over a calm side channel of the river at the base of the canyon cliff during 2 nights of netting. At this site 2 Eptesicus gobiensis (Bobrinski, 1926), 5 Myotis brandtii (Eversmann, 1845), 6 Myotis daubentoni (Kuhl, 1817), and 16 Vespertilio murinus Linnaeus, 1758 were examined for parasites. The second site, Ulziyt Uul $\left(44^{\circ} 41^{\prime} 09^{\prime \prime} \mathrm{N}, 102^{\circ} 00^{\prime} 57^{\prime \prime} \mathrm{E}, 1,640 \mathrm{~m}\right.$ elevation) is a small barren rocky hill in the arid Gobi Steppe north of Arts Bogd Mountain. The area consists of sparse vegetation (Allium, Stipa, and Artemesia) and desert pavement. Bats were collected during 1 night by netting at the base of the hill as well as by shotgun as they circled camp. Six individuals of E. gobiensis were examined for parasites from this locality.

Insectivores were collected from 2 localities. One adult shrew (Sorex caecutiens Laxmann, 1788) was captured in Gorkhi-Terelj National Park $\left(47^{\circ} 53^{\prime} \mathrm{N}, 107^{\circ} 23^{\prime} \mathrm{E}\right)$ in a Sherman live trap on a narrow mountaintop ridge $(2,000 \mathrm{~m})$ in Pinus sibirica forest. Five hedgehogs (Hemiechinus auritus (Gmelin, 1770)) were captured in Tomahawk live traps and by hand at Ulziyt Uul, and 1 was caught at the base of

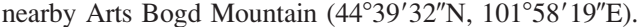

Four species of pika were captured from 3 different localities. Two individuals of Ochotona alpina (Pallas, 1773) and 3 Ochotona dauurica (Pallas, 1776) from Ulaan Tsutgaalan, 2 Ochotona hyperborea (Pallas, 1811) from talus slopes at Gorkhi-Terelj, and 2 Ochotona pallasi (Gray, 1867) from Ulziyt Uul were examined.

Captured animals were processed immediately following standard protocols (Gardner, 1996). Each animal was brushed and examined for ectoparasites, a blood smear was made for later examination for microfilariae or hemoprotozoa, and fecal samples were collected for study of coccidia following the method of Vance and Duszynski (1985) and Gardner (1996). The complete gastrointestinal tract, liver, lungs, pleural cavity, and peritoneal cavity were examined separately for helminths. Gastrointestinal tracts of 3 individuals $(2 \mathrm{H}$. auritus, $1 \mathrm{O}$. hyperborea $)$ were preserved and stored in $70 \%$ ethanol $(\mathrm{ETOH})$ until examined in the Harold W. Manter Laboratory of Parasitology (HWML). From complete field necropsies, specimens were preserved in $10 \%$ formalin or $70 \%$ ETOH for study by light microscopy. Trematode and cestode specimens were stained with carmine, cleared in xylene or terpineol, mounted in Damar gum, and observed with a microscope. Nematode specimens were preserved in $10 \%$ formalin, cleared in lactophenol, and observed with a microscope. Measurements are presented as range, with mean, standard variation, and sample size in parentheses. Specimens were deposited in the Harold W. Manter Laboratory of Parasitology (HWML).

\section{RESULTS}

Five taxa of helminths were collected from 4 of the 10 host species examined. Uninfected mammals included S. caecutiens, M. brandtii, M. daubentoni,
$O$. dauurica, O. hyperborea, and $O$. pallasi. Host, parasite, locality, and infection parameters are outlined below for those mammals found to harbor parasites.

\section{Chiroptera}

\section{Vespertilio murinus Linnaeus, 1758}

\section{Trematoda}

\section{Plagiorchis vespertilionis (Müller, 1780)}

Collection locality: Ulaan Tsutgaalan.

Site of infection: Posterior 1/16 of intestine.

Prevalence and intensity: 2/16 (12.5\%), 4.

Specimens deposited: HWML48487, HWML48488, HWML48490.

Additional hosts from Mongolia: This represents the first record from the country.

Type host and type locality: Plecotus auritus, Denmark; Neotype host designated by Tkach et al. (2000) as M. daubentoni, Kiev, Ukraine.

Other reported hosts: In central Asia Plagiorchis vespertilionis has been reported from numerous bat species including Eptesicus serotinus (Schreber, 1774); Myotis mystacinus (Kuhl, 1817); Myotis oxygnathus Monticelli, 1885; Nyctalus noctula (Schreber, 1774); Pipistrellus pipistrellus (Schreber, 1774); P. auritus; Eptesicus nilssoni (Keyserling and Blasius, 1839) (see Spasski et al., 1952; Groschaft and Tenora, 1974; Tokobaev, 1976). Other reported hosts from across its range have included members of Myotis Kaup, 1829; Pipistrellus Kamp, 1829; Plecotus E. Geoffrey SaintHillare, 1818; Nyctalus Bowdich, 1825; Nyctinomops Miller, 1902; Rhinolophus Lacepede, 1799; Tadarida Rafinescque, 1820; and Miniopterus Bonaparte, 1837 (see Yamaguti, 1958); as well as Barbastella barbastella (Schreber, 1774) and possibly from paratenic rodent hosts (Tkach et al., 2000).

Geographic range: This species is known from across the Palearctic (Yamaguti, 1958; Tkach et al. 2000); although reported from the Nearctic, these reports may be erroneous (Tkach et al. 2000). In central Asia it has been reported from Kirgizia (Tokobaev, 1976); Yakutia, and Lake Baikal in Russia (Spasski et al., 1952); Afghanistan (Groschaft and Tenora, 1974); Tadjikistan (Spasski et al., 1952).

Remarks: The morphological variation seen in $P$. vespertilionis across its range and its presence in 
such a variety of bat hosts has made identification and taxonomic status of its synonyms problematic. Our specimens conform to those of the redescription by Tkach et al. (2000) of $P$. vespertilionis from the Ukraine, although there are a few discrepancies. Our specimens are very elongate; length 1.5-2.7 $(2.3 \pm 0.5, n=7) \mathrm{mm}$; maximum width, usually at level of acetabulum, 302-503 (373 $\pm 71, n=7) \mu \mathrm{m}$; length/width ratio 3.6-8.4:1 (6.4:1 $\pm 1.8, n=7)$. Tegument covered with small spines, which reach to posterior margin of posterior testis, diminishing in number as they progress posteriad. Distance between middle of oral sucker and acetabulum 333-774 $(560 \pm 152, n=7) \mu \mathrm{m}$. Vitelline fields end anterior to ovary, not reaching ventral sucker. Cirrus sac elongate, curving under the acetabulum, from medially to across the right margin. Oral sucker round to slightly oval 155-209 × 155-194 (187 \pm $20 \times 179 \pm 16, n=7) \mu \mathrm{m}$. Ventral sucker round or slightly oval, slightly smaller on average than oral sucker $124-178 \times 116-155(150 \pm 18 \times 133 \pm 15$, $n=5) \mu \mathrm{m}$. Sucker ratio $1: 1.14-1.25(1: 1.25 \pm 0.08$, $n=7)$.

Eptesicus gobiensis (Bobrinski, 1926)

\section{Trematoda}

\section{Plagiorchis vespertilionis (Müller, 1780)}

Collection locality: Ulziyt Uul.

Site of infection: Posterior 1/16 of intestine, near rectum.

Prevalence and intensity: 1/6 (16.67\%), 2.

Specimens deposited: HWML63032, HWML48489.

Remarks: See comments under Vespertilio murinus.

\section{Nemata}

Filaroidea gen. sp.

Collection locality: Ulziyt Uul.

Site of infection: Body cavity.

Prevalence and intensity: 1/6 (16.67\%), 1.

Specimens deposited: HWML48491.

Remarks: One partial individual was recovered from the body cavity. Since Litomosa Yorke and Maplestone, 1926 is the only genus of filaroid nematode known from Old World bats, this individual likely represents a member of that genus.

\section{Insectivora}

Hemiechinus auritus (Gmelin, 1770)

\section{Acanthocephala}

\section{Moniliformis moniliformis}

(Bremser in Rudolphi, 1811)

Collection locality: Ulziyt Uul.

Site of infection: Anterior end small intestine.

Prevalence and intensity: 1/6 (16.67\%), 1.

Specimens deposited: HWML63026.

Additional hosts from Mongolia: Moniliformis moniliformis has been previously reported from $H$. auritus; Mesechinus dauuricus (Sundevall, 1842); Spermophilus undulatus (Pallas, 1778); Spermophilus erythrogenus Brandt, 1841; Meriones meridianus (Pallas, 1773); and Microtus arvalis (Pallas, 1778) (see Danzan, 1978; Ganzorig et al., 1988).

Other reported hosts and range: This species has been reported from a variety of insectivorous and carnivorous mammals across Eurasia, Africa, and Pacific Islands (Yamaguti, 1963; Tokobaev, 1976; Deveaux et al. 1988).

Remarks: A second species, Moniliformis clarki (Ward, 1917), has also been reported from Phodopus sungorus (Pallas, 1773); Allocricetulus curtatus (Allen, 1925); Marmota sibirica (Radde, 1862); and S. undulatus in Mongolia (Danzan 1978; Ganzorig, 1998). Some of the previous reports of M. moniliformis in $S$. undulatus may in fact represent $M$. clarki (see Ganzorig, 1998, unpublished thesis, Graduate School of Veterinary Medicine, Hokkaido University, Japan).

\section{Lagomorpha}

Ochotona alpina (Pallas, 1773)

Cestoda: Anoplocephalidae

Schizorchis mongoliensis n. sp.

(Figs. 1-7)

\section{Description}

Intact strobila ranging from 18.2 to 20.2 (19.5 \pm $0.9, n=4) \mathrm{mm}$ long, with up to 68 proglottids. One individual cestode was found with additional loose segments (identifiable definitively as coming from that specimen); adding these would increase the overall length of this specimen to $30.1 \mathrm{~mm}$. Maximum width of strobila 2.6-3.2 (2.8 $\pm 0.3, n=$ 4) $\mathrm{mm}$ attained in late gravid segments (Fig. 7). Strobila widens rapidly after scolex (Fig. 5). Strobila 

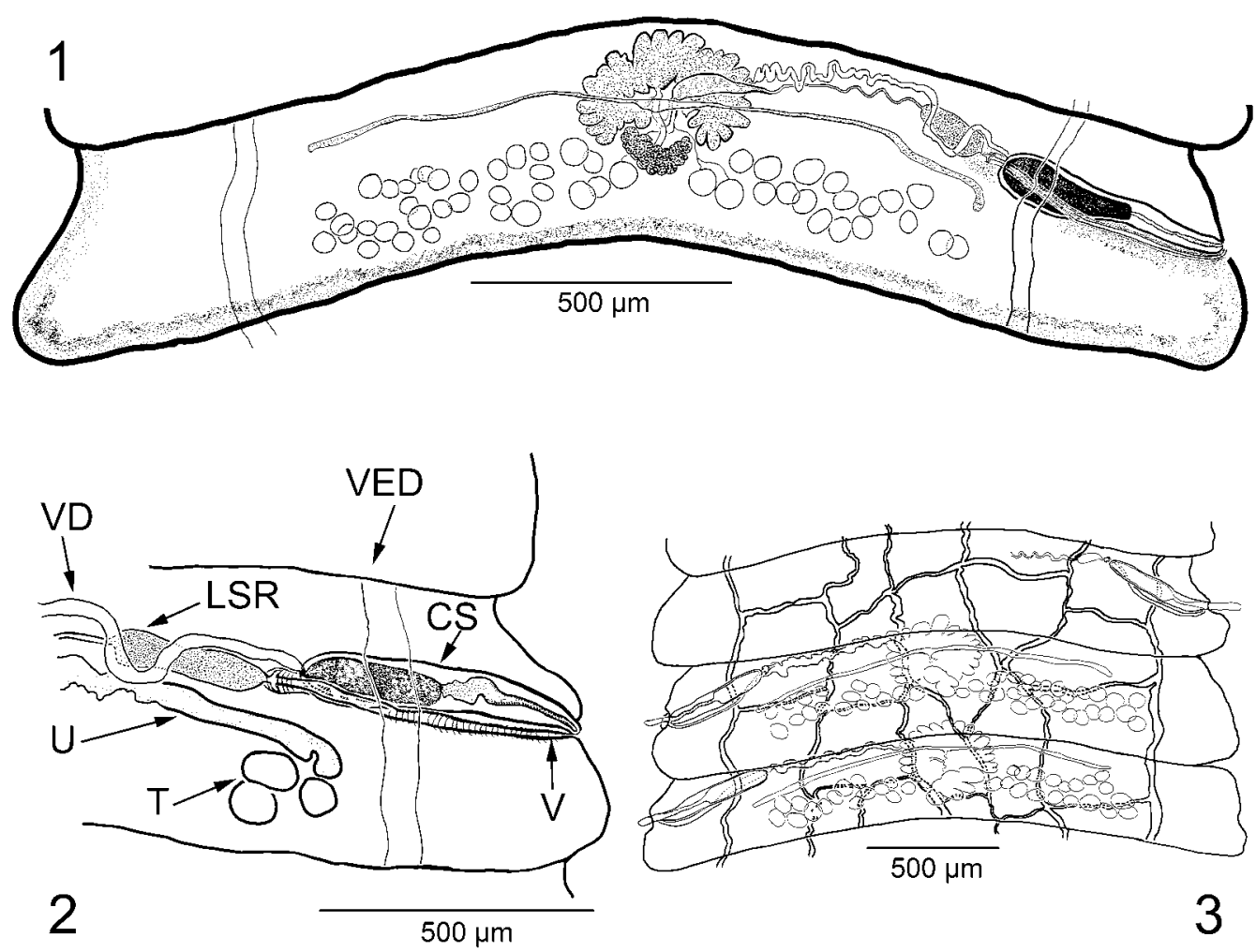

Figures 1-3. Schizorchis mongoliensis n. sp. 1. Mature proglottid, ventral view. 2. Details of genital ducts showing lateral seminal receptacle and muscular vaginal valve. CS, cirrus sac; LSR, lateral seminal receptacle; VD, vas deferens; VED, ventral excretory duct; V, vagina; T, testes; U, Uterus. 3. Mature proglottid detailing system of accessory excretory canals, dorsal view.

craspedote. All segments wider than long with mature segments having a length/width ratio of 1:4.9-1:6.3 $(1: 5.8 \pm 0.6, n=4)$ and gravid segments $1: 4.0-1: 4.5$ $(1: 4.2 \pm 0.2, n=4)$. When viewed from either dorsal or ventral aspect, all segments with characteristic arch shape, lateral edges more posterior relative to median part (Figs. 1, 3, 5, and 7). Scolex 215-250 (232 \pm 18 , $n=3) \mu \mathrm{m}$ in width, suckers $78-92(83 \pm 5, n=12)$ $\mu \mathrm{m}$ in diameter, neck 108-170 $(149 \pm 36, n=3) \mu \mathrm{m}$ in length. Anlagen of genitalia appears immediately following neck in first proglottids. Genital pores irregularly alternating and positioned slightly anterior to transverse midline of each segment. Ventral excretory canal 9-22 $\mu \mathrm{m}$ in diameter and undulating. Transverse canal crosses proglottid at approximately the level of the testes field. Accessory canals connecting transverse canals forming an irregular branching longitudinal network (Fig. 3). Dorsal excretory canal not clearly distinguishable. Testes $30-50$ in number generally in discrete lateral groups somewhat more numerous antiporally. Testes ovoid to round, 51-91
$(64 \pm 9, n=38) \mu \mathrm{m}$ in diameter. Cirrus sac elongate, 433-596 (540 $\pm 37, n=30) \mu \mathrm{m}$ in diameter, approaching maximum size in mature proglottids, proximal end somewhat inflated, angled anteromedially, ending along the proglottid margin. Cirrus sac extends beyond the excretory canals; proximal end even with uterus and testes. Internal seminal vesicle well defined and elongate, 152-251 (208 $\pm 26, n=$ 20) $\times 45-96(63 \pm 10, n=20) \mu \mathrm{m}$. Vas deferens tubular, not forming pronounced vesicular sac, tubular form slightly undulating, but not forming deep pronounced coils, extending mediad across anterior portion of proglottid before angling posteriad between ovary and seminal receptacle. Vagina thick walled $16-23 \mu \mathrm{m}$ in diameter, positioned posterior and ventral to cirrus sac, curving anteriad and overlapping cirrus sac mediad, ending slightly proximal to cirrus sac, with a distinct muscular valve (Figs. 1, 2, and 4). Both vagina and cirrus sac lie dorsal to excretory canals. After muscular end of vagina, female genital duct immediately enlarging into a discrete sac 

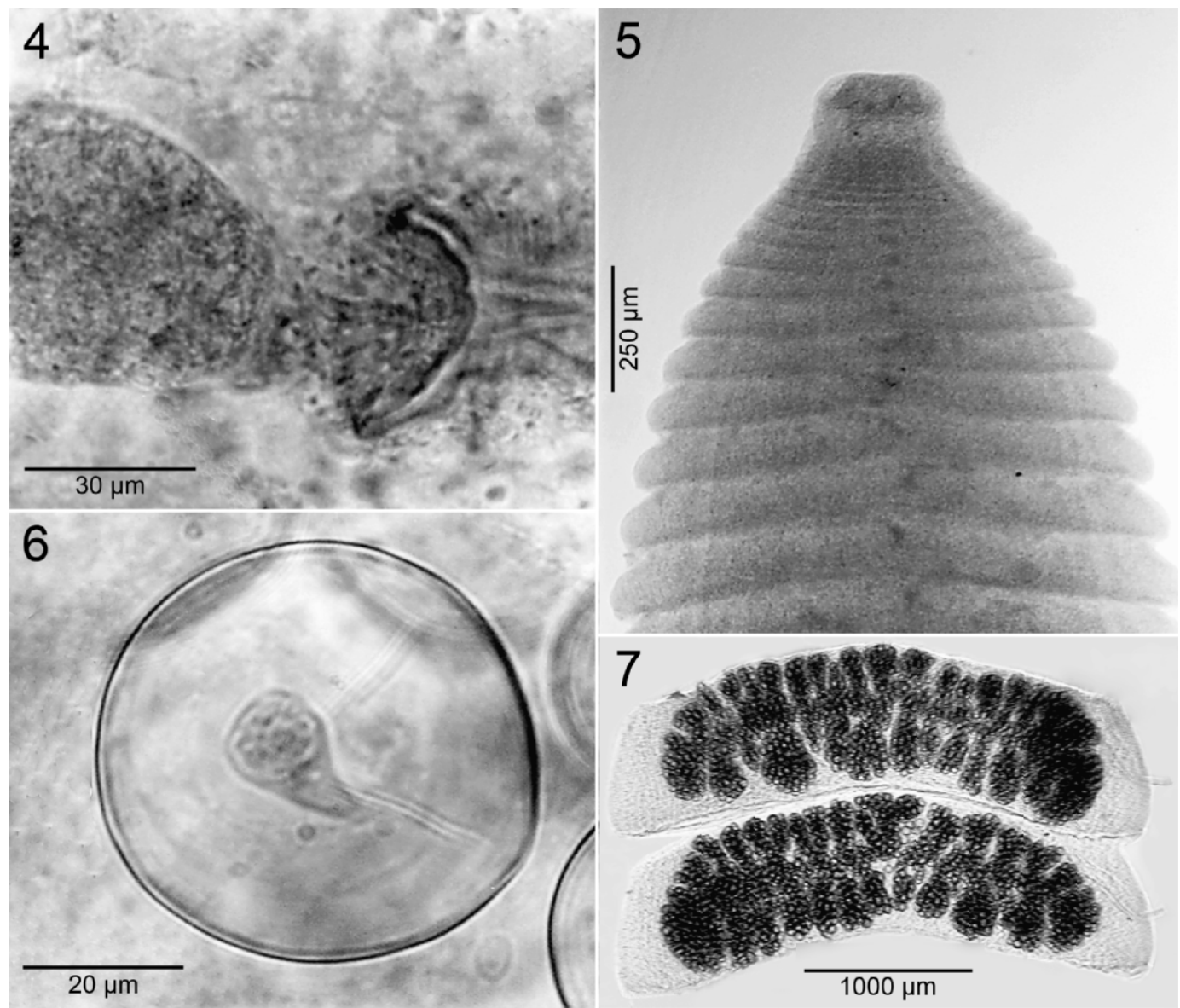

Figures 4-7. Schizorchis mongoliensis n. sp. 4. Micrograph detailing vaginal valve and connection with lateral seminal receptacle. 5. Micrograph showing anterior portion of specimen. 6. Micrograph of egg. 7. Micrograph of gravid proglottids.

$136-225(178 \pm 1, n=15) \times 30-56(41 \pm 8, n=15)$ $\mu \mathrm{m}$ (Figs. 1, 2, and 4), the lateral seminal receptacle. Genital duct then narrows to a small tube before reaching medial seminal receptacle, which lies dorsal to ovary. Ovary 176-254 (222 $\pm 5, n=12) \mu \mathrm{m} \times$ 351-566 (432 $\pm 67, n=12) \mu \mathrm{m}$ with small lobes, situated medially, extending to anterior margin of proglottid and ventrally slightly past anterior edge of vitelline gland. Vitelline gland slightly lobed 90-125 $(110 \pm 12, n=12) \mu \mathrm{m} \times 105-168(145 \pm 20$, $n=12) \mu \mathrm{m}$. Uterus tubular and bilateral, extending to end of testes field and proximal end of cirrus sac (Figs. 1, 2). Eggs first appear at approximately the 44th proglottid, first as a mass in 1 distal end of the uterus, usually the antiporal side. Uterus forms anterior and posterior sacculations in gravid proglottids (Fig. 7). In gravid proglottids, uterus extending beyond end of cirrus sac, but not past the ventral excretory canal. Cirrus and vagina persist in gravid segments. Eggs round to slightly oval 46-75 (56 \pm 7 , $n=40) \mu \mathrm{m}$ in diameter, egg membrane smooth and thin, less than $2 \mu \mathrm{m}$ in thickness. Onchosphere with pyriform apparatus. Width of onchosphere 15-23 $(20 \pm 2, n=60) \mu \mathrm{m}$ (Fig. 6).

\section{Taxonomic Summary}

Type host: Ochotona alpina (Pallas, 1773) Symbiotype (see Frey, et al., 1992) deposited in the University of New Mexico, Museum of Southwestern Biology Mammal Division (MSB), MSB94337.

Type locality: Ulaan Tsutgaalan, Ovorkhangay Aimag, Mongolia, 46 $47^{\prime} 13^{\prime \prime} \mathrm{N}, 101^{\circ} 57^{\prime} 47^{\prime \prime} \mathrm{E}, 1850 \mathrm{~m}$ elevation.

Site of infection: Small intestine. 
Type specimen: Holotype, mounted on slide, collected 17 July 1999, HWML48485A, paratypes, from same host symbiotype, mounted on slides, HWML 48485B-D; and 1 vial, HWML62980.

Prevalence and intensity: 1/2 (50\%), 6 (4 fully developed, 2 immature).

Etymology: The specific epithet refers to Mongolia, the country from which this new species was collected.

\section{Differential Diagnosis}

Schizorchis mongoliensis n. sp. is most similar to Schizorchis altaica Gvozdev, 1951 and Schizorchis ryzhikovi Rausch and Smirnova, 1984. It is distinguished from $S$. altaica in general size characters being significantly shorter, up to $20.2 \mathrm{~mm}$, in intact strobila, versus up to $150 \mathrm{~mm}$ total length in $S$. altaica (measured by Gvozdev 1951) or $68 \mathrm{~mm}$ in specimens examined from Ochotona rutilla (Severtzov, 1873) in Kazakhstan by Rausch and Smirnova (1984). The maximum number of segments found in S. mongoliensis was 68 versus 188 reported by Rausch and Smirnova (1984) from S. altaica, while the last mature proglottid of $S$. mongoliensis was found to be segment 44 versus 76 in $S$. altaica. Testes number in S. mongoliensis are fewer (30-50) relative to $S$. altaica (50-60), and the eggs in $S$. mongoliensis are slightly smaller, 46-75 $\mu \mathrm{m}$ versus 46-85 $\mu \mathrm{m}$, and they are smooth with a thin egg membrane, while those of $S$. altaica are covered in fine projections and thick skinned, $>2 \mu \mathrm{m}$ (Rausch and Smirnova, 1984). However, Spasski and Rhizhikov (1951) provided counts of the testes (40-50) and diameter of the eggs $(47-60 \mu \mathrm{m})$ from specimens they ascribed to $S$. altaica that were collected from a different locality (near Lake Baikal) than that of the type locality for $S$. altaica in Kazakhstan as recorded by Gvosdev (1951). The specimens collected from near Lake Baikal show some overlap in these 2 measurements with $S$. mongoliensis.

Although strobila length is approximately equal between S. mongoliensis and S. ryzhikovi (20-36 mm), $S$. mongoliensis contains only 68 segments, while $S$. ryzhikovi contains up to 131 proglottids with the last mature proglottid in S. mongoliensis at number 44 versus 56-65 in S. ryzhikovi. The ovary of S. mongoliensis is less distinctly lobed than in S. ryzhikovi. The eggs of $S$. mongoliensis are much smaller than those of S. ryzhikovi $(66-90 \mu \mathrm{m})$. Finally, the occurrence of a distinct muscular valve at the end of the vagina (Figs. 2,3 ) in addition to the pronounced lateral seminal receptacle (Figs. 1, 2, 3) in the female reproductive tract clearly distinguishes $S$. mongoliensis from both $S$. altaica and S. ryzhikovi, which have neither.

The muscular vaginal valve and lateral seminal receptacle, as well as length of strobila (maximum $20 \mathrm{~mm}$ ), number of segments (maximum 68), and last mature proglottid (44), serve to distinguish S. mongoliensis from the other species in the genus, all of which have measurements exceeding these. For a complete summary of species in the genus Schizorchis, with a table of comparative data, see Rausch and Smirnova (1984).

\section{Remarks}

Cestodes of the genus Schizorchis (Hansen, 1948) have been reported from pikas from both Asia and North America (Hansen, 1948; Gvozdev, 1951; Rausch, 1960; Rausch, 1963; Rausch and Smirnova 1984). At the present time 7 species are known, only from ochotonids, but Rausch and Smirnova (1984) indicated that a relatively large amount of morphological variation is shown by some of these species and additional work may reveal undescribed forms within this complex.

Two other species of Schizorchis have been reported from Mongolian Ochotona: S. altaica has been reported from $O$. dauurica in the southern Mongolian Altai Mountains region and O. hyperborea from the northern part of the country (Danzan, 1978; Ganzorig, 1998, unpublished thesis, Graduate School of Veterinary Medicine, Hokkaido University, Japan). Schizorchis ryzhikovi has also been reported from $O$. pallasi in the Mongolian Altai (Ganzorig, 1998, unpublished thesis, Graduate School of Veterinary Medicine, Hokkaido University, Japan). One of us (S.G.) collected 2 incomplete specimens, lacking gravid proglottids, from the type locality of $S$. mongoliensis in 1996. They were morphologically similar (including the muscular vaginal valve), and we determined that they represent the same species. Additional collections need to be done in this area to confirm the species range.

\section{Cestoda: Catenotaeniidae \\ Catenotaenia sp.}

Collection locality: Ulaan Tsutgaalan.

Site of infection: Small intestine.

Prevalence and intensity: 1/2 (50\%), 1.

Specimens deposited: HWML48486.

Remarks: One partial specimen was recovered, which conforms with Catenotaenia Janicki, 1904. 
Scolex $387 \mu \mathrm{m}$ in width, suckers pouched 172$178 \mu \mathrm{m}$ in diameter. Strobila consisting of 15 immature proglottids length $5.5 \mathrm{~mm}$, proglottids longer than wide $521 \times 347 \mu \mathrm{m}$. Currently 3 species of Catenotaenia are known from Mongolian rodents, Catenotaenia dendritica (Goetze, 1782); Catenotaenia asiatica Tenora and Murai, 1975; and Catenotaenia afghana Tenora, 1977 (see Ganzorig, Tenora, et al., 1999). Since members of the genus Catenotaenia are primarily known to infect rodent hosts, this could be an accidental infection.

\section{DISCUSSION}

Approximately twice the size of Texas, Mongolia is situated at the center of central Asia's biodiversity. Because of the unique geographic location of the country, several major biomes and ecosystems converge in this area, including alpine, taiga, forest steppe, steppe, desert steppe, and desert (Tinnin et al., 2002; Jargal, 2003). Elevations range from a minimum of $560 \mathrm{~m}$ in the eastern steppe/desert to a maximum of 4,374 $\mathrm{m}$ at Khuiten peak in the western most Altai mountains. In montane regions of Mongolia the geographic relief creates many intermountain pockets of isolated and fragmented habitats. Even though these areas may harbor hidden or undiscovered biological diversity, modern extensive biodiversity surveys in Mongolia are sorely lacking, particularly in regard to the sylvatic mammal/endoparasite fauna.

Data obtained and analyzed on both mammals and their parasites provides detailed habitat information that could not be collected in any other way (Manter, 1966; Gardner and Campbell, 1992; Brooks and Hoberg, 2000; Hoberg et al., 2003). The presence, in mammals and other vertebrates, of parasites that have complex life cycles provides a clear window on otherwise "cryptic information" relative to ecological habits, trophic interactions, home range size, historical ecology, phylogenetic relationships, and biogeography of the mammal species under investigation. Complete knowledge of a fauna in a region will also reveal the presence of any actual or potential zoonoses that might exist there (Brooks and Hoberg, 2000; Hoberg, et al., 2003). In addition, we have shown that data on parasites with complex life cycles, when combined with knowledge of the phylogenetic relationships of both host and parasite, can be used as probes for areas of great biological diversity (Gardner and Campbell, 1992; Brooks and Hoberg, 2000).

Of the approximately 100 species of rodents, lagomorphs, bats, and insectivores that are currently known from Mongolia, only 20 have been examined for helminths. Of those species, only half have had more than 10 individuals in total examined. Eighty percent of all specimens investigated were from 2 species Lasiopodomys brandti (Radde, 1861), 61\%, and S. undulatus, $19 \%$. The results of this study increased the number of known helminths to 33 . However, we estimate that between 320 and 420 species of helminths (Cestoda, Nemata, Trematoda, and Acanthocephala) occur in the small mammals of the country (Brooks and Hoberg, 2000; Gardner, 2000; Brooks and McLennan, 2002). This rough estimate is based on extensive faunal surveys of Kirgizia, Tadjikistan, Kazakhstan, Uzbekistan, and Turkmenistan (Tokobaev, 1976). This in fact may be a conservative estimate due to the large number of isolated habitats and potentially undescribed endemic mammals present in Mongolia. Based on our initial analyses, it appears that a gap of biodiversity knowledge exists in the country (Tinnin et al., 2002; Tinnin and Gardner, unpublished data).

\section{ACKNOWLEDGMENTS}

Funding was provided NSF grant DEB0717214 and supplements to grants DEB9631295 to S.L.G. and DBI9411976. Additional support was provided by NIH grant (1PO1AI39780) and the Harold W. Manter Laboratory Development Fund. Thanks to Hugh Genoways for watching over our work here in the Manter Laboratory.

\section{LITERATURE CITED}

Brooks, D. R., and E. P. Hoberg. 2000. Triage for the biosphere: the need and rationale for taxonomic inventories and phylogenetic studies of parasites. Comparative Parasitology 67:1-25.

Brooks, D. R., and D. A. McLennan. 2002. The Nature of Diversity: An Evolutionary Voyage of Discovery. University of Chicago Press, Chicago. 668 pp.

Danzan, G. 1978. Helminths of the wild mammals in Mongolia. D.Sc. Thesis, Moscow, VIGIS.

Deveaux, T. P., G. D. Smith, and M. Krishnasamy. 1988. Two new species of Moniliformis (Acanthocephala: Moniliformidae) from Malaysia. Journal of Parasitology 74:322-325.

Frey, J. K., T. L. Yates, D. W. Duszynski, W. L. Gannon, and S. L. Gardner. 1992. Designation and curatorial management of type host specimens (symbiotypes) for new parasite species. Journal of Parasitology 78:930 932.

Ganzorig, S., N. Batsaikhan, Y. Oku, and M. Kamiya. 2003. A new nematode, Soboliphyme ataahai sp. n. (Nematoda: Soboliphymidae) from Laxmann's shrew, Sorex caecutiens Laxmann, 1788 in Mongolia. Parasitology Research 89:44-48.

Ganzorig, S., N. Batsaikhan, R. Samiya, Y. Morishima, Y. Oku, and M. Kamiya. 1999. A second record of 
adult Ascarops strongylina (Rudolphi, 1819) (Nematoda: Spirocercidae) in a rodent host. Journal of Parasitology 85:283-285.

Ganzorig, S., G. Danzan, J. Burmaa, and B. Enhutuya. 1988. New findings of helminths from mammals in Huvsgul area. Pages 120-121 in Natural Conditions and Resources of Some Regions of Mongolia, Irkutsk State University, Irkutsk, Russia.

Ganzorig, S., Y. Oku, A. Gubányi, F. Tenora, and M. Kamiya. 1996. New record of taeniid larvae from Daurian pika, Ochotona daurica (Lagomorpha) in Mongolia. Parasitologia Hungarica 29:39-44.

Ganzorig, S., D. Sumiya, N. Batsaikhan, R. Schuster, Y. Oku, and M. Kamiya. 1998. New findings of metacestodes and a pentastomid from rodents in Mongolia. Journal of the Helminthological Society of Washington 65:74-81.

Ganzorig, S., F. Tenora, Y. Oku, and M. Kamiya. 1999. New records of catenotaeniid cestodes from rodents in Mongolia, with notes on the taxonomy of the Catenotaenia Janicki, 1904 and Hemicatenotaenia Tenora, 1977 (Cestoda: Catenotaeniidae). Acta Universitatis Agriculturae et Silviculturae Mendelianae Brunensis 47:33-38.

Gardner, S. L. 1996. Field parasitology techniques for use with mammals. Pages 291-298 in D. E. Wilson, F. R. Cole, J. D. Nichols, R. Rudram, and M. S. Foster, eds. Measuring and Monitoring Biological Diversity: Standard Methods for Mammals. Smithsonian Institution Press, Washington, DC. 409 pp.

Gardner, S. L. 2000. Worms, Nematoda. Pages 843-862 in Levin, S. A., ed. Encyclopedia of Biodiversity, Volume 5, Academic Press, San Diego, California. $1103 \mathrm{pp}$

Gardner, S. L., and M. Campbell. 1992. Parasites as probes for biodiversity. Journal of Parasitology 78: 1744-1759.

Groschaft, J., and F. Tenora. 1974. Some remarks on the morphological variability of the species Plagiorchis vespertilionis (Muller, 1780) and Plagiorchis koreanus Ogata, 1938 (Trematoda, Plagiorchidae) parasitizing bats. Acta Universitas Agriculturae Facultas Agronomica, Brno 22:115-130.

Gvozdev, E. V. 1951. A new species of cestode of the family Anoplocephalidae from pikas. Trudi Gelmintologicheskoi Laboratorii Akademii Nauk SSSR 5:143145.

Hansen, M. F. 1948. Schizorchis ochotonae n. gen., n. sp. of Anoplocephalid cestode. American Midland Naturalist 39:754-757

Hoberg, E. P., S. J. Kuntz, K. E. Galbreath, and J. A. Cook. 2003. Arctic biodiversity: from discovery to faunal baselines-revealing the history of a dynamic process. Journal of Parasitology 89(Supplement): 84-95.

Jargal, J. 2003. Protected area status in Mongolia. Mongolian Journal of Biological Sciences 1:49-54.

Mallon, D. P. 1985. The mammals of the Mongolian People's Republic. Mammal Review 15:71-102.

Manter. H. 1966. Parasites of fishes as biological indicators of recent and ancient conditions. Pages 59-71 in J. E. McCauley ed. Host Parasite Relationships. Oregon State University Press, Corvalis, Oregon. 148 pp.
Meszaros, F. 1974. Some nematodes from small mammals in Eastern Mongolia. Parasitologia Hungarica 7:151168.

Rausch, R. L. 1960. Studies on the helminth fauna of Alaska. XXXVII Description of Schizorchis caballeroi n. sp. (Cestoda: Anoplocephalidae), with notes on other parasites of Ochotona. Pages 399-405 in Libro Homenaje al Dr. Eduardo Caballero y Caballero. Instituto Poltitechnico Nacional, Mexico. 593 pp.

Rausch, R. L. 1963. Schizorchis yamashitai sp. n. (Cestoda:Anoplocephalidae) from the northern pika Ochotona hyberborea Pallas in Hokkaido. Journal of Parasitology 49:479-482.

Rausch, R. L., and L. V. Smirnova. 1984. The genus Schizorchis (Cestoda: Anoplocephalidae) in Eurasian pikas, Ochotona spp. (Lagomorpha: Ochotonidae), with descriptions of new species. Transactions of the American Microscopical Society 103:144-156.

Reading, R. P., S. Amgalanbaatar, and L. Lhagvasuren. 1999. Biological assessment of Three Beauties of the Gobi National Conservation Park, Mongolia. Biodiversity and Conservation 8:1115-1137.

Reading, R. P., H. Mix, B. Lhagvasuren, and E. S. Blumer. 1999. Status of wild Bactrian camels and other large ungulates in southwest Mongolia. Oryx 33: 247.

Suhbat, H., and S. Ganzorig. 1998. The biology of Mustela evesrmanni in Mongolia. Scientific Reports of the Mongolian State University 99:229-238.

Spasski, A. A., and K. M. Rhizhikov. 1951. Helminths of pikas of Prebaikal. Trudi Gelmintologicheskoi Laboratorii Akademii Nauk SSSR 5:34-41.

Spasski, A. A., K. M. Rizhikov, and V. E. Sudarikov. 1952. The helminth fauna of wild mammals in the region of Lake Baikal. Trudi Gelmintologicheskoi Laboratorii Akademii Nauk SSSR 6:85-113.

Tenora, F., and E. Murai. 1975. Cestodes recovered from rodents (Rodentia) in Mongolia. Annales HistoricoNaturales Musei Nationalis Hungarici 67:65-70.

Tinnin, D. S., J. L. Dunnum, J. Salazar-Bravo, N. Batsaikhan, M. S. Burt, S. L. Gardner, and T. L. Yates. 2002. Contributions to the mammalogy of Mongolia, with a checklist of species for the country. Special Publication of the Museum of Southwestern Biology Number 6. 38 pp.

Tkach, V. V., J. Pawlowski, and V. P. Sharpilo. 2000. Molecular and morphological differentiation between species of the Plagiorchis vespertilionis group (Digenea, Plagiorchiidae) occurring in European bats, with a re-description of $P$. vespertilionis (Müller, 1780). Systematic Parasitology 47:9-22.

Tokobaev, M. M. 1976. Helminths of Wild Mammals of Central Asia. Akademi Nauk Kirgizia SSR. 179 pp.

Vance, T. L., and D. W. Duszynski. 1985. Coccidian parasites (Apicomplexa: Eimeriidae) of Microtus spp. (Rodentia: Arvicolidae) from the United States, Mexico, and Japan, with descriptions of five new species. Journal of Parasitology 71:302-311.

Yamaguti, S. 1958. Systema Helminthum. Volume 1. The Digenetic Trematodes of Vertebrates, Part I. Interscience Publishers, New York. 978 pp.

Yamaguti, S. 1963. Systema Helminthum. Volume V. Acanthocephala. Interscience Publishers, New York. 423 pp. 